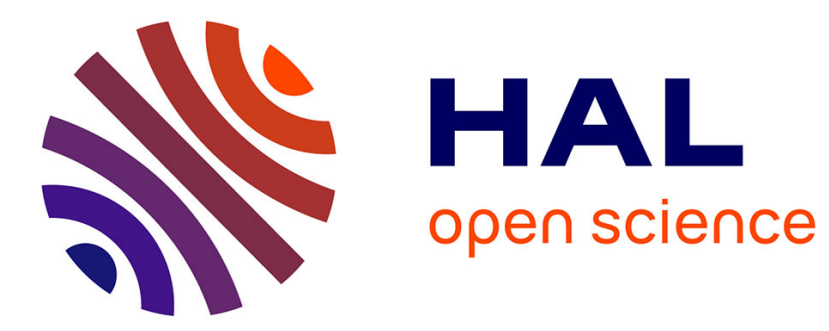

\title{
Oxygen consumption rates in deep-sea hydrothermal vent scale worms: effect of lifestyle, oxygen concentration, and temperature sensitivity
}

Victor Le Layec, Stéphane Hourdez

\section{- To cite this version:}

Victor Le Layec, Stéphane Hourdez. Oxygen consumption rates in deep-sea hydrothermal vent scale worms: effect of lifestyle, oxygen concentration, and temperature sensitivity. Deep-sea research. Part A, Oceanographic research papers, 2021, 172 (103531), pp.103531. 10.1016/j.dsr.2021.103531 . hal03188733

\section{HAL Id: hal-03188733 \\ https://hal.sorbonne-universite.fr/hal-03188733}

Submitted on 2 Apr 2021

HAL is a multi-disciplinary open access archive for the deposit and dissemination of scientific research documents, whether they are published or not. The documents may come from teaching and research institutions in France or abroad, or from public or private research centers.
L'archive ouverte pluridisciplinaire HAL, est destinée au dépôt et à la diffusion de documents scientifiques de niveau recherche, publiés ou non, émanant des établissements d'enseignement et de recherche français ou étrangers, des laboratoires publics ou privés. 
Oxygen consumption rates in deep-sea hydrothermal vent scale worms: effect of lifestyle, oxygen concentration, and temperature sensitivity

Victor Le Layec ${ }^{1,2}$, Stéphane Hourdez ${ }^{2 *}$

1- UMR 7144, Adaptation et Diversité en Milieu Marin, Station Biologique de Roscoff, Place

G. Teissier, 29680 Roscoff, France

2- UMR 8222, Laboratoire d'Ecogéochimie des Environnements Benthiques, Observatoire

Océanologique de Banyuls, Avenue Pierre Fabre, 66650 Banyuls-sur-Mer, France

* Corresponding author 


\begin{abstract}
Deep-sea hydrothermal vents are a challenging environment inhabited by very specialized species. To reap the benefits of the local primary production, species need to cope with a number of constraints among which low oxygen is probably the most basic. This hypoxia is further complicated by the highly variable temperature these species experience. We studied the response of deep-sea hydrothermal species of scale worms (Annelida, Polynoidae) to varying levels of oxygen and showed that they were capable of compensating a decrease of environmental oxygen concentration (= oxyregulators), down to values of about $30 \mu \mathrm{mol} .1^{-1}$. This contrasts with shallow-water temperate species, for which oxygen consumption is directly proportional to its concentration (= oxyconformers). We measured oxygen consumption rates in 11 species from hydrothermal vents, as well as 2 species from the general deep-sea, and compared them to three shallow-water species. Life-style (free-living vs. commensal) and habitat of origin (shallow-water, deep-sea, and hydrothermal vent) did not affect oxygen consumption rates. In agreement with thermodynamic expectations, as temperature increases, oxygen consumption increases as well for all species. The sensitivity of oxygen consumption to temperature variation in the shallow-water species is however smaller than that from the deep-sea hydrothermal vent species. This unexpected result could correspond to a pronounced increase of activity (avoidance behavior) in the vent species, which was not observed for the shallow-water species.
\end{abstract}




\section{Introduction}

Deep-sea hydrothermal vents are high-biomass ecosystems in comparatively barren surroundings (Tunnicliffe, 1992). They rely on local primary production by chemo-autotrophic microorganisms that use the oxidation of reduced chemical compounds such as $\mathrm{H}_{2} \mathrm{~S}, \mathrm{H}_{2}, \mathrm{CH}_{4}$ and $\mathrm{Fe}^{2+}$ contained in the hydrothermal fluid as an energy source (Childress and Fisher, 1992; Van Dover and Fry, 1994).

Despite the seemingly attractive character of this environment, the conditions encountered there can be very challenging. In particular, the mixing of the hot hydrothermal fluid with the very cold surrounding deep-sea water is very chaotic and, as result, temperature and chemistry vary widely and rapidly (Childress and Fisher, 1992). The pure hydrothermal fluid is devoid of oxygen, rich in $\mathrm{CO}_{2}$, low $\mathrm{pH}$, and contains toxic compounds such as $\mathrm{H}_{2} \mathrm{~S}$, and heavy metals $(\mathrm{Hg}, \mathrm{Cd}, \mathrm{Zn}, \ldots)$. As a result, organisms can be exposed to varying levels of hypoxia (low oxygen), hypercapnia (high $\mathrm{CO}_{2}$ ), and low $\mathrm{pH}$. This is most likely one of the main drivers for the high rate of endemicity of the fauna found near deep-sea hydrothermal vents. Hypoxia is a major challenge, and its effect can be complicated by the positive correlation between temperature and hypoxia of the water surrounding the organisms (Hourdez and Lallier, 2007). The few studies on metabolic needs suggest that deep-sea hydrothermal vent crabs and annelids (Childress and Mickel, 1985; Hourdez and Lallier, 2007) have oxygen consumption rates similar to those of non-vent relatives. Other studies have focused on adaptations to chronic hypoxia in hydrothermal vent invertebrates, considering the morphology, physiology, and blood functional properties (Hourdez and Lallier, 2007). Morphological studies have mostly focused on the gills of invertebrates, and showed that while vent-dwelling annelids possess increased gill surface areas, vent crustaceans usually do not (Decelle et al., 2010; Hourdez and Lallier, 2007). Similarly, gills from vent-dwelling annelids exhibit reduced diffusion distances that facilitate the diffusion of gases (Hourdez and Lallier, 2007) but vent-dwelling crustaceans do not display this adaptation (Decelle et al., 2010). Crabs and shrimp from hydrothermal vents however possess greater ventilatory capacity (increased scaphognathite surface area) compared to shallow-water temperate relatives (Decelle et al., 2010). Studies on Bythograea thermydron (Gorodezky and Childress, 1994) and Segonzacia mesatlantica (Hourdez, 2018) have shown that these crabs can regulate their oxygen uptake to compensate for the decrease of environmental concentration down to very low levels compared to shallow-water relatives. This oxyregulation does not involve a modification of the heart rate but most likely relies on a modification of the ventilation rate (Hourdez, 2018). 
Most hydrothermal vent organisms possess circulating respiratory pigments (hemocyanin and hemoglobin) in their body fluids (Hourdez and Lallier, 2007). Interestingly, circulating respiratory pigments were even found in representatives of some taxonomic groups that were formerly known for lacking them (e.g. Polynoidae annelids; Hourdez and Lallier, 2007). The sheer presence of respiratory pigments could represent a form of oxygen storage for periods of anoxia. In addition, they can facilitate oxygen diffusion by binding this gas inside the body. This is further aided by the very high affinity for oxygen these molecules exhibit, leaving only very low partial pressures of free oxygen in the fluids (Hourdez and Jollivet, 2021; Hourdez and Lallier, 2007).

The very dynamic nature of the vent environment, and in particular the rapid variations of temperature experienced by the deep-sea hydrothermal vent organisms has prompted a great deal of interest to understand the limits and tolerance mechanisms of response and adaptation to this parameter (Hourdez and Jollivet, 2021). In shallow-water marine environments, temperature follows a seasonal pattern, varying by about $2^{\circ} \mathrm{C}$ throughout the year in Antarctic waters to nearly $20^{\circ} \mathrm{C}$ in some temperate areas (Sunday et al., 2011). In marine species, thermal tolerance breadth increases with latitude before decreasing near the poles (Sunday et al., 2011). At deep-sea hydrothermal vents, species appear to be distributed in correlation with temperature, ranging from $2-3^{\circ} \mathrm{C}$ (standard temperature of deep-sea water) to about $40^{\circ} \mathrm{C}$ on the walls of chimneys (Desbruyères et al., 1982). However, even at a fixed location, temperature can vary widely over short periods of time (Bates et al., 2010; Johnson et al., 1988, 1986). In this highly variable environment, metazoans seem to seek cooler conditions compared to shallow-water species in respect to their respective actual upper temperature tolerance (Bates et al., 2010).

In situ observations usually provide a good picture of the thermal environment encountered by the different species but the very steep gradients of conditions (over centimeter scales) and the inherent difficulties of working in the deep sea represent a serious challenge to properly characterize the actual living conditions of these organisms. The species Alvinella pompejana, a hydrothermal vent chimney wall dweller, illustrates this well. An early observation showed a specimen curled around a temperature probe indicating $105^{\circ} \mathrm{C}$ (Chevaldonné et al., 1992), and in situ measurements suggested the worms were continuously exposed to temperature between 60 and $80^{\circ} \mathrm{C}$ (Cary et al., 1998). These values are greatly in excess of upper temperature limits measured for various biochemical processes in this species (Chevaldonné et al., 2000). More recent work on live specimens in pressurized aquaria revealed that a $2 \mathrm{~h}$ exposure to $50-55^{\circ} \mathrm{C}$ was lethal for the worms and that they were unlikely to withstand 
environmental temperatures greater than $50^{\circ} \mathrm{C}$ for extended periods of time (Ravaux et al., 2013), in better agreement with the aforementioned biochemical processes.

Annelids represent an important proportion of the endemic biodiversity at hydrothermal vents, and, among them, scale worms (Polynoidae) are the most diverse (Tunnicliffe, 1992). These scale worms are found in all microhabitats where metazoans are present, from the coldest (and therefore most oxygenated) areas where the influence of the hydrothermal vent fluid is minimal, to the warmest possibly most hypoxic areas such as on chimney walls. Different species occupy different ranges of temperature, and of chemical conditions that are correlated to this temperature (Desbruyères et al., 1982; Podowski et al., 2010). These species are usually free-living and can move to avoid adverse conditions, but species of the genus Branchipolynoe are commensal with mussels and therefore have limited mobility. This family is found in many other environments, from shallow-water to the deep-sea, from polar to tropical waters. It is very diverse, with about 900 species, and lends itself well to comparative work.

The present study aimed at determining the metabolic requirements and thermal tolerance of scale worms of the family Polynoidae from hydrothermal vents and compare them to shallowwater species of the same family. To that end, we worked with specimens placed in pressurized aquaria maintained at in situ pressure and measured oxygen consumption rates. We investigated the effect of life-style, environmental oxygen concentration and temperature on these rates to seek potential characteristics with an adaptive value in vent species. 


\section{Materials and methods}

Three types of experiments were carried out: oxygen consumption rates, oxyregulation, and temperature sensitivity of oxygen consumption.

\section{Sampling and abiotic parameters}

Samples were collected from a variety of locations and habitats (Table 1). In total, 17 species were studied. Specimens were either collected near the Roscoff marine laboratory, or during different scientific expeditions on deep-sea hydrothermal vents: on the East Pacific Rise (cruises EPR2002, MESCAL 1, and MESCAL 2), on the Mid-Atlantic Ridge (TRANSECT cruise), and in the West Pacific (CHUBACARC cruise). Finally, a species was collected from an expedition at cold seeps in West Africa (WACS cruise). All experiments on deep-sea animals were performed onboard research vessels and those on shallow-water species in the lab. Details of the species, numbers of specimens for each type of experiments are provided in table 1. Typical temperatures encountered by each species are also indicated. Studies with in situ measurements of oxygen concentration values are very scarce and indicate that values typically range from $80 \pm 48$ to $144 \pm 22 \mu \mathrm{mol} .1^{-1}$ for different animal assemblages, to $175 \mu \mathrm{mol} .1^{-}$

1 in ambient water (Johnson et al., 1986; Podowski et al., 2010, 2009). No data are available for cold-seep assemblages and for hydrothermal-vent chimney walls. Shallow-water species are usually exposed to air-saturated water which concentration depends on temperature (200$\left.260 \mu \mathrm{mol} . \mathrm{l}^{-1}\right)$. All experiments used natural seawater (36-38 ppt) that was filtered on $1 \mu \mathrm{m}$ (cartridge filters).

\section{Oxyregulation}

In a first set of experiments, we aimed to study the capacity of different species to compensate a decrease of environmental oxygen concentrations to meet their metabolic demand (oxyregulation). Each experiment was performed on a single individual in a flow-through system at in situ pressure (provided by High Pressure Liquid Chromatography pumps, see Hourdez, 2018) and at a temperature of $10^{\circ} \mathrm{C}$. Once placed in the flow-through vessels, animals were allowed to recover for 10-12 hours before experimentation started. Oxygen concentration was measured with an optode (NeoFox, Ocean Optics) placed in the outflow of the system (i.e. after the pressure relief valve), either after flowing through the aquarium containing the specimen or after flowing through a tubing that bypassed the aquarium (Hourdez, 2018). Oxygen consumption was calculated based on the water flow rate of the HPLC pump, and the 
difference of oxygen concentration between the aquarium and bypass paths. Runs without animals were used as controls to remove oxygen consumption due to bacteria. Oxygen concentration in the seawater feeding the aquarium was modified by bubbling either air (to reach air saturation) or nitrogen (to decrease the oxygen concentration) in the water. After outflow oxygen concentration reached a plateau, oxygen consumption was measured as described above. Oxygen concentration was ramped up or down in succession (i.e. not constantly going down) to mimic environmental concentration changes and avoid acclimation.. Overall, these experiments lasted for about 36 hours for each individual and were performed for 7 species and 9 individuals in total ( 3 specimens for $B$. aff. seepensis; see Table 1). These numbers include two shallow-water temperate species, one cold-seep species, and four deepsea hydrothermal vent species. No deep-sea non-vent species could be used for this type of experiment.

\section{Oxygen consumption rates}

In another set of experiments, simple oxygen consumption experiments were carried out. For deep-sea species, two types of experiments were carried out. In the first type, hereafter referred to as 'closed vessel' the specimens were individually placed in a gas-tight Hamilton syringe that was in turn placed into a large pressure vessel. In the second type of experiments, a specimen was individually placed into a flow-through vessel as described above. For shallowwater species, the oxygen consumption was measured in the flow-through system only, allowing us to keep the environmental oxygen concentration provided constant. Temperature of incubation was controlled by placing the pressure vessel into a water-bath at the desired temperature $\left( \pm 0.2^{\circ} \mathrm{C}\right)$. All reported consumption rates were measured at $10^{\circ} \mathrm{C}$. The water used in the incubations and flow-through was bubbled with air contained typically 200-260 $\mu$ mol.1'

${ }^{1}$ of oxygen, depending on room temperature.

For the closed vessels, after 1.5 to 2.5 hours, a water sample was carefully withdrawn from the syringe containing the specimen and the gas contents of the water was measured with a gas chromatograph (GC) (Arp and Childress, 1983). Oxygen consumption was calculated based on the volume of water in the syringe, oxygen concentration difference, and duration of the incubation. Syringes that contained no animals were used as control for bacterial consumption.

For flow-through vessels, animals were allowed to recover for 10-12 hours before experimentation started. Oxygen consumption was calculated as described above for the oxyregulation experiments. Runs without animals were used as controls to remove oxygen consumption due to bacteria. Because the animals are able to move inside the pressure vessel 
and go between periods of acitivty and rest, oxygen consumption was measured every 2 hours, 3 or 4 times and the average consumption is reported.

Overall, each individual oxygen consumption experiment lasted between 3 hours for closed vessel experiments and 16-24 hours for flow-through experiments. A total of 99 specimens representing 17 species were used in these experiments. Details of specimens and species used for each type of oxygen consumption experiment are provided in Table 1.

The demonstration of the capacity to oxyregulate for hydrothermal vent species (see Results) allows us to directly compare measurements made in flow-through and closed chambers for these species.

\section{Temperature sensitivity}

In the last set of experiments, we measured oxygen consumption rates as temperature was regularly increased in the flow-through vessel $\left(6{ }^{\circ} \mathrm{C} / \mathrm{h}\right)$. Start temperature was typically $6^{\circ} \mathrm{C}$ (close to deep-sea temperature at these depths) and the experiment was ended when the specimen displayed signs of death (ventriflexion and lack of movement). Most experiments ended at about $37^{\circ} \mathrm{C}$ (about 6 hours total). For shallow-water species, start temperature was about $10^{\circ} \mathrm{C}$ to not induce cold stress and was ended when the animals displayed signs of death. The experiments ended at about $30^{\circ} \mathrm{C}$, for a total duration of about 2.5 hours. The setup was the same as described above, the source seawater was continuously bubbled with air to maintain air saturation ( $c a .260 \mu \mathrm{mol}^{-1} \mathrm{l}^{-1}$ oxygen in inlet), and the oxygen consumption was measured in the outlet after the pressure-relief valve. To reflect the highly variable conditions encountered at hydrothermal vents, no acclimation period was given to the specimens. This experiment was performed on a total of 9 specimens (see tables 1 and 2), including one shallowwater species (one specimen), one deep-sea (one specimen) and 4 hydrothermal vent species (one or two specimens each). This type of experiment was not performed on the cold-seep species. Because the specimens went through periods of activity and rest, it was not possible to determine an Arrhenius Break Point (ABP).

\section{Experimental specimen preservation and weighing}

All animals were preserved after in $85 \%$ ethanol after the experiments and their wet weight was measured on an analytical balance (Mettler Toledo, precision $0.001 \mathrm{~g}$ ) after returning to the lab. 
For oxyregulation experiments, the curve described in Hourdez (2018) was used to fit to the datapoints and determine the oxygen concentration below which oxyregulation was no longer possible (critical oxygen concentration).

The relationship between oxygen consumption rates and wet weight was linearized using a $\log / \log$ transform. Because some species and groups are represented by few individuals, a linear regression was used on the whole dataset and deviations from this regression were used for comparison. The residuals to this relationship were calculated and compared to see whether species from different habitats had different oxygen requirements. 


\section{Results}

Capacity to oxyregulate

We measured oxygen consumption rates and the effect of oxygen concentration on this consumption at $10^{\circ} \mathrm{C}$ for four different species from deep-sea hydrothermal vents, a cold-seep species (at $4^{\circ} \mathrm{C}$ ), and two shallow-water temperate species (Figure 1). For the coastal species Pettibonesia furcosetosa and Harmothoe extenuata (Figure 1A), over the range $200 \mu \mathrm{mol}^{-1} \mathrm{I}^{-1}$ to $50 \mu \mathrm{mol}^{-1} \mathrm{I}^{-1}$, the consumption decreases with the concentration of oxygen in the environment. In contrast, over the same range, all hydrothermal vent species and the cold-seep species (Figure 1B) the oxygen consumption remains relatively constant. Below this lower concentration, there is a sharp drop at about an oxygen concentration of $30 \mu \mathrm{mol}^{-\mathrm{l}^{-1}}$ in the environment.

The capacity to extract the same amount of oxygen from the environment regardless of its concentration (oxyregulation) has been observed for all hydrothermal vent species, including Lepidonotopodium fimbriatum, which does not possess gills (Figure 1B). For Branchinotogluma segonzaci (Figure 1B), we did not reach the limit below which the animal was not able to maintain its oxygen consumption (lowest oxygen concentration of $30 \mu \mathrm{mol.1} \mathrm{l}^{-1}$ in the aquarium). The value below which the other species are no longer capable of oxyregulation and oxygen consumption reaches zero is about $25 \mu \mathrm{mol}^{-1}$ for Lepidonotopodium fimbriatum (Figure 1B) and Branchipolynoe aff. seepensis (Figure 1B), and probably lower for Thermopolynoe branchiata (Figure 1B), although there are too few data points below that value for confidence.

\section{Effect of size, life-style and habitat of origin}

We measured oxygen consumption rates at $10^{\circ} \mathrm{C}$ for 99 specimens representing 2 species from deep-sea non-vent areas, 11 from deep-sea hydrothermal vents, and three shallow-water temperate species (Figure 2). For all specimens pulled together, there is a correlation between the consumption rate and the size of the animal (Figure 2A), and the specific oxygen consumption rate (per gram wet weight) decreases as the wet weight of the animal increases $\left(\mathrm{r}^{2}=0.2481, \mathrm{p}<0.001\right.$, slope -0.353$)$.

To detect whether life style or the environment had an effect of the oxygen consumption rates, we calculated the residuals to the correlation established for the whole dataset (Figure 2B). All deep-sea hydrothermal vent (free-living and commensal) and non-hydrothermal vent abyssal species have a similar oxygen consumption ( $p$-value $<0.05)$. Although difficult to directly compare because the consumption of the shallow-water species depends on oxygen 
concentration and the limited availability of coastal replicates for this comparison, the coastal specimens do not have a significantly higher consumption rate than the deep-sea ones (Oneway ANOVA $\mathrm{p}<0.0001)$. The cold-seep species was studied at $4^{\circ} \mathrm{C}$ and its consumption rates cannot be directly compared to all the other species (experiments performed at $10^{\circ} \mathrm{C}$ ).

\section{Effect of temperature on oxygen consumption rates}

During the experiments to study the effect of temperature, the animals went through phases of activity and rest, which manifested as rises and falls in oxygen consumption (Figure 3). Overall, throughout the experiment, their activity increased with temperature (pers. obs.). At higher temperature values, we observed spasms and ventriflexion which are characteristics of imminent death of the animals. None of the experimental animals survived temperatures greater than $38^{\circ} \mathrm{C}$. For the shallow-water species, death occurred at much lower temperature than vent species $\left(\mathrm{ca} .27^{\circ} \mathrm{C}\right.$; Figure $\left.3 \mathrm{~A}\right)$. For all species, the oxygen consumption rate increases with temperature.

Overall, the slopes of the linear part ranged from -1.17 for the shallow-water species Gattyana cirrhosa to -3.49 for one specimen of the hydrothermal vent chimney species Branchinotogluma segonzaci (Supplementary figure 1 and Table 2). For three of the six species tested, two specimens were tested and showed some variability in response to increasing temperature. For two of the species, the slope only varies by $0.3-0.6$ but for $B$. segonzaci, the two specimens yielded two very different slopes (-1.56 and -3.49 ; supplementary figure $1 \mathrm{~B}$ and C). For all hydrothermal vent species, the slope was greater (i.e. the oxygen consumption rates are more sensitive to temperature variation) than the shallow-water temperate species Gattyana cirrhosa and the deep-sea species Thermiphione sp.. At higher temperature, oxygen consumption reaches an inflexion point that could be interpreted as the Arrhenius break point (ABP), although the slope rupture is not sharp and an accurate determination is not possible (Figure 3). 


\section{Discussion}

Oxyregulation in hydrothermal vent species

Animals can be classified as either oxyregulators or oxyconformers according to their respiratory response to hypoxia (Prosser, 1955). Oxyregulators have the capacity to regulate their oxygen uptake to compensate variations of the environmental concentration of this gas, while oxygen consumption is proportional to environmental oxygen concentration in oxyconformers. While anaerobic energy production starts at high oxygen partial pressures for oxyconformers, oxyregulators do not rely on this metabolism until a partial pressure under which oxygen consumption decreases sharply and the organism increasingly relies on anaerobic metabolism. Our data on Polynoidae show that the littoral species Pettibonesia furcosetosa and Harmothoe extenuata fall into the oxyconformer category, while all hydrothermal vent species tested for this capacity are oxyregulators. Sthenelais boa, a species of the closely-related scale worm family Sigalionidae, also falls into the oxyconformer category (Cosgrove and Hajduk, 1980). The fact that oxyregulation was so far only encountered in hydrothermal vent species could indicate that this is a derived character in these species. This interpretation is consistent with our current understanding of scale worm phylogeny (Norlinder et al., 2012), in which the vent species form a monophyletic group and the two shallow-water species of Polynoidae and the Sigalionidae are basal. However, additional non-vent Polynoidae species and members of closely related families need to be studied to reliably determine the ancestral state of the response to varying environmental oxygen concentrations.

The capacity to oxyregulate relies on compensatory mechanisms that can involve ventilation, diffusion, or circulatory responses (see Hourdez and Lallier, 2007 for a review on adaptation to chronic hypoxia). In general, in scale worms, including Polynoidae, water circulation is produced by ciliary movements at the surface of the body. In the shallow-water species Halosydna brevisetosa, the elytra form a roof that allows a directional and effective flow of water from the front to the posterior end of the animal (Lwebuga-Mukasa, 1970). Scale worms usually lack gills but some hydrothermal vent species possess segmental coelomic gills (Hourdez and Jouin-Toulmond, 1998). These gills increase the gas exchange surface area and offer reduced diffusion distances compared to the typical body-wall through which gas exchange occurs in other species of scale worms. Our work shows that regardless of the presence of gills, all tested hydrothermal vent species are capable of oxyregulation, and that this character does not seem to affect the critical partial pressure of oxygen below which the animals can no longer compensate. In the genus Branchipolynoe, elytra are usually reduced in 
size but they still cover the gills (that are attached to the parapodia) and likely participate in the efficient water flow over the gills (that bear numerous cilia; Hourdez and Jouin-Toulmond, 1998), where most of the oxygen exchange occurs. This genus is also commensal in the mantle cavity of bathymodiolin mussels, and can benefit from the water flow produced by their host. A common character of hydrothermal vent species compared to shallow-water species is the presence of hemoglobin in large amounts in their coelomic fluid (Hourdez et al., 1999b, 1999a; Projecto-Garcia et al., 2017). In contrast, shallow-water species all lack a circulating respiratory pigment and only exhibit small amounts of globin in their nervous system (Hourdez et al., 1999a; Weber, 1978). The vascular system is poorly developed in all scale worms and oxygen diffuses through the epidermis to reach the coelomic fluid that bathes all the internal organs. The coelomic epithelium is ciliated and therefore the fluid circulates. It is unknown whether this circulation rate can be modified as a possible response to low oxygen values. Hemoglobins in the species studied so far exhibit a high affinity for oxygen that likely facilitates oxygen diffusion into the body (Hourdez et al., 1999b, 1999a; Projecto-Garcia et al., 2017). The presence of high-affinity hemoglobins however is not always associated with the capacity to oxyregulate. In the giant tubeworm Riftia pachyptila (Annelida, Siboglinidae) for example, oxygen consumption is directly proportional to oxygen partial pressure (=oxyconformers; Girguis and Childress, 2006). Conversely, some invertebrates devoid of respiratory pigments such as mussels can oxyregulate if the temperature is not too high (Jansen et al., 2009). May, (1972) showed that two species of annelids (Abarenicola pacifica (Arenicolidae) and Lumbrineris zonata (Lumbrineridae)) exhibited an oxyregulatory capacity in summer but not in springtime. In our case, we did not test this capacity in summertime and it is possible that shallow-water species could exhibit an oxyregulatory capacity in summer. If this capacity exists, the absence of high-affinity respiratory pigments would likely limit the critical partial pressure for these species. In the hydrothermal bythograeid crabs Bythograea thermydron and Segonzacia mesatlantica, the critical partial pressure can be linked to the high affinity of the hemocyanin (Gorodevsky and Childress, 1994; Hourdez, 2018). Shallow-water species of crabs can also oxyregulate but the critical partial pressure is much higher, reflecting the much lower affinity of their hemocyanin for oxygen (e.g. critical oxygen concentration 100-130 mol.1 $^{-1}$ in Carcinus maenas; Taylor, 1976). 
The capacity to oxyregulate allows us to directly compare oxygen consumption rates obtained from flow-through (shallow-water, some East Pacific Rise measurements and West Pacific species) and closed-vessel experiments (remaining East Pacific Rise measurements).

Overall, once the weight of specimens and temperature are considered, the oxygen consumption rates measured here are well in the typical range reported for other annelids (Weber, 1978; Childress and Mickel, 1985). The specific consumption rates are slightly higher for shallow-water species at high environmental oxygen concentration but drops below that of deep-sea species at values lower than $150 \mu \mathrm{mol}^{-1} \mathrm{l}^{-1}$ oxygen. The lack of oxyregulation capacity for shallow-water species therefore makes it difficult to compare oxygen consumption rates. All consumption rates were measured using air-saturated water (ca. $260 \mu \mathrm{mol}^{-1^{-1}}$ at the temperature at which the experimental system was maintained). It is not clear whether deepsea, non-vent species are capable to oxyregulate but their specific consumption rates seem to be slightly lower than in shallow-water species (although the difference is not significant). Oxygen consumption increases with activity level, including in tube-dwelling groups (Weber, 1978). Although Branchipolynoe, a genus that is commensal with bathymodiolin mussels, could be expected to have a lower activity level than free-living species, there is no significant difference of specific oxygen consumption rate between these two lifestyles at $10^{\circ} \mathrm{C}$.

Besides the difference in oxyregulation, all species studied here consume very similar amounts of oxygen. The absence of such difference between deep-sea and shallow-water relatives was already reported in other taxonomic groups by Childress and Mickel (1985): crustaceans, bivalves, and an array of polychaeta. These authors concluded that the metabolic rates of benthic deep-sea animals are not related to the food availability. Hydrothermal vent communities indeed benefit from large quantities of locally produced biomass (by autotrophic bacteria) compared to the very small amounts of photosynthetic biomass falling from surface. This contrasts with pelagic groups with image-forming eyes that exhibit a decrease of metabolic rates with increasing depth (related to changes in locomotor capacities), although evolutionary history also has a strong importance (Seibel, 2007).

As typically observed in other animals, while the oxygen consumption rate increases with body size, the specific oxygen consumption rate (i.e. consumption per gram body weight) decreases with body size. The higher oxygen consumption rate could reflect a higher investment in growth in smaller individuals. For our dataset, the relationship between size and specific oxygen consumption rates follows an allometric relationship with a coefficient of 0.35 , close to the value reported in the classical studies of the 1960's for annelids (e.g. 0.33 in Banse et 
al., 1971). This value indicates that the metabolic rate is proportional to the surface area of the animals rather than their body weight (Weber, 1978).

\section{Effect of temperature}

Temperature constrains every biological process, in particular metabolic processes (Hochachka and Somero, 1984). Accordingly, oxygen consumption rates increased with temperature for all species tested. Because of the succession of rest and active periods throughout the experiment, the determination of an Arrhenius Break Point was difficult. However, shallow-water species died in slightly lower temperature than deep-sea species $\left(27^{\circ} \mathrm{C}\right.$ vs. $30-38^{\circ} \mathrm{C}$, respectively). More than absolute values, temperature variability and the organisms' response to this variability may be limiting their distribution around hydrothermal vents. In earlier experiments, authors have shown that eurythermal species typically exhibit less sensitivity to temperature variation than species that naturally experience a more limited range of temperature (see Mangum, 1978). These studies, however, were performed on species that experience either very stable temperatures (general deep-sea) or seasonal changes of temperatures, and specimens were given 9-21 days of acclimation at the desired temperature. Deep-sea hydrothermal vent species are exposed to temperature changes that can reach 10 degrees over a few minutes. In our study, specimens were not acclimated to the desired temperature to better mimic the hydrothermal vent environment. Contrary to our expectations, while inhabiting a highly variable environment, the oxygen consumption of the deep-sea hydrothermal vent species exhibited a greater sensitivity to temperature variation (greater Arrhenius slope values). A single shallow-water temperate species was studied for this response, and additional species should to be investigated to confirm this observation. The marked variability observed within a species could be evidence for acclimation, the replicates coming from distinct collections. This would also need to be confirmed through further measurements on specimens from a single collection point, and from distinct sites. All hydrothermal vent species were very active in the aquaria when the temperature increased, while the shallow-water species, although more active, did not show such a higher degree of activity (pers. obs.). This difference of behaviour could be a reflexion of the early onset of avoidance behaviour of hydrothermal vent species which attempt to remain at temperatures well below their lethal threshold compared to temperate species (Bates et al., 2010). These authors indicate that avoidance of hot conditions is a primary defence strategy used by ectotherms from the tropics and deserts but not specifically displayed by temperate marine fauna. This latter fauna is more likely to experience tidal or seasonal thermal variations but not the rapid and chaotic spikes of 
temperature that characterize hydrothermal vents. As a consequence, for instance, most vent molluscs (provannids, limpets or bivalves) are usually located at a distance from vent flows, with temperature variability oscillating between 5 and $15^{\circ} \mathrm{C}$, and other species represent true stenothermal abyssal taxa, with temperatures that do not exceed $4^{\circ} \mathrm{C}$ (Bates et al., 2005, 2010). The oxygen and capacity-limited thermal tolerance (OCLTT) concept provides an explicative framework to study and understand the thermal range of aquatic animal species (Pörtner et al., 2017). In this concept, oxygen limitation takes a central role in the thermal tolerance of species. The capacity to oxyregulate for species from hydrothermal vents likely also provides them a better thermal tolerance or a wider thermal range than for shallow-water species.

\section{Conclusions}

In conclusion, for the species investigated in this study, only hydrothermal vent species can oxyregulate down to oxygen concentrations as low as $30 \mu \mathrm{mol}^{-1} \mathrm{l}^{-1}$, while shallow-water species are oxyconformers. Oxygen consumption rates are not different comparing contrasted lifestyles (free-living vs. commensal, shallow-water vs. deep-sea vs. hydrothermal vent). Surprisingly, although hydrothermal vent species are exposed to highly variable temperatures (ca. $10^{\circ} \mathrm{C}$ over a few minutes), their oxygen consumption rates do not exhibit a reduced sensitivity to temperature variation. On the contrary, oxygen consumption increases more strongly with temperature in vent species. This could provide higher energy for the animals to escape from conditions too close to lethal temperatures.

\section{Acknowledgements}

We are grateful to the chief scientists, ship crews, and deep submersible pilots and technicians for the access to the specimens used in this study. We would like to thank Jim Childress for not only allowing us to use his equipment on the EPR2002 cruise but also kindly offering his critical reading of this manuscript. Many thanks to Cécile Cathalot for lending us an optode in replacement of a defective one during the CHUBACARC cruise. Thank you to Alexis Lecoeur for his help running experiments during the MESCAL cruise. This research was supported by the Région Bretagne HYPOXEVO program, the CERBERUS research program (ANR-17CE02-0003), the Fonds Flotte Océanographique, and the Flotte Océanographique Française.

\section{Declaration of interests}

The authors declare that they have no known competing financial interests or personal relationships that could have appeared to influence the work reported in this paper. 

References

Arp, A. J. and J. J. Childress, 1983. Sulfide binding by the blood of the hydrothermal vent tube worm Riftia pachyptila. Science, 219, 295-297. https://doi.org/10.1126/science.219.4582.295

Banse, K., Nichols, F.N., May, D.R., 1971. Oxygen consumption by the seabed. III. On the role of the macrofauna at three stations. Vie Milieu 22, 31-52.

Bates, A., Tunnicliffe, V., Lee, R., 2005. Role of thermal conditions in habitat selection by hydrothermal vent gastropods. Mar. Ecol. Prog. Ser. 305, 1-15. https://doi.org/10.3354/meps305001

Bates, A.E., Lee, R.W., Tunnicliffe, V., Lamare, M.D., 2010. Deep-sea hydrothermal vent animals seek cool fluids in a highly variable thermal environment. Nat. Commun. 1, 14. https://doi.org/10.1038/ncomms1014

Cary, S.C., Shank, T., Stein, J., 1998. Worms bask in extreme temperatures. Nature 391, 545546.

Chevaldonné, P., Desbruyéres, D., Childress, J.J., 1992. . . . and some even hotter. Nature 359, 593-594. https://doi.org/10.1038/359593b0

Chevaldonné, P., Fisher, C., Childress, J., Desbruyères, D., Jollivet, D., Zal, F., Toulmond, A., 2000. Thermotolerance and the "Pompeii worms." Mar. Ecol. Prog. Ser. 208, 293295. https://doi.org/10.3354/meps208293

Childress, J.J., Fisher, C.R., 1992. The biology of hydrothermal vent animals: Physiology, biochemistry, and autotrophic symbioses. Oceanogr. Mar. Biol. Annu. Rev. 30, 337441.

Childress, J.J., Mickel, T.J., 1985. Metabolic rates of animals from the hydrothermal vents and other deep-sea habitats. Biol. Soc. Wash. Bull. 6, 249-260.

Cosgrove, W.B., Hajduk, S.L., 1980. The effect of environmental oxygen concentration on the rate of oxygen consumption of the polychaete Sthenelais boa (Johnston). Cah. Biol. Mar. 21, 123-133.

Decelle, J., Andersen, A.C., Hourdez, S., 2010. Morphological adaptations to chronic hypoxia in deep-sea decapod crustaceans from hydrothermal vents and cold seeps. Mar. Biol. 157, 1259-1269. https://doi.org/10.1007/s00227-010-1406-8

Desbruyères, D., Crassous, P., Grassle, J.F., Khripounoff, A., Reyss, D., Rio, M., Van Praët, M., 1982. Données écologiques sur un nouveau site de hydrothermalisme actif de la ride du pacifique oriental. Comptes Rendus Académie Sci. Paris Sér. III 295, 489-494.

Girguis, P.R., Childress, J.J., 2006. Metabolite uptake, stoichiometry and chemoautotrophic function of the hydrothermal vent tubeworm Riftia pachyptila: responses to environmental variations in substrate concentrations and temperature. J. Exp. Biol. 209, 3516-3528. https://doi.org/10.1242/jeb.02404

Gorodezky, L.A., Childress, J.J., 1994. Effects of sulfide exposure history and hemolymph thiosulfate on oxygen-consumption rates and regulation in the hydrothermal vent crab Bythograea thermydron. Mar. Biol. 120, 123-131.

Hochachka, P.W., Somero, G.N., 1984. Biochemical adaptation.

Hourdez, S., 2018. Cardiac response of the hydrothermal vent crab Segonzacia mesatlantica to variable temperature and oxygen levels. Deep Sea Res. Part Oceanogr. Res. Pap. 137, 57-65. https://doi.org/10.1016/j.dsr.2018.03.004 
Hourdez, S., Jollivet, D., 2021. Metazoan adaptation to deep-sea hydrothermal vents, in: Life in Extreme Environments. Insights in Biological Capability, Ecological Reviews. Cambridge University Press, pp. 42-67.

Hourdez, S., Jouin-Toulmond, C., 1998. Functional anatomy of the respiratory system of Branchipolynoe species (Polychaeta, Polynoidae), commensal with Bathymodiolus species (Bivalvia, Mytilidae) from deep-sea hydrothermal vents. Zoomorphology 118, 225-233. https://doi.org/10.1007/s004350050071

Hourdez, S., Lallier, F.H., 2007. Adaptations to hypoxia in hydrothermal-vent and cold-seep invertebrates. Rev. Environ. Sci. Biotechnol. 6, 143-159. https://doi.org/10.1007/s11157-006-9110-3

Hourdez, S., Lallier, F.H., Green, B.N., Toulmond, A., 1999a. Hemoglobins from deep-sea hydrothermal vent scaleworms of the genus Branchipolynoe: a new type of quaternary structure. Proteins 34, 427-434. https://doi.org/10.1002/(SICI)10970134(19990301)34:4<427::AID-PROT2>3.0.CO;2-L

Hourdez, S., Lallier, F.H., Martin-Jézéquel, V., Weber, R.E., Toulmond, A., 1999b. Characterization and functional properties of the extracellular coelomic hemoglobins from the deep-sea, hydrothermal vent scaleworm Branchipolynoe symmytilida. Proteins Struct. Funct. Genet. 34, 435-442. https://doi.org/10.1002/(SICI)10970134(19990301)34:4<435::AID-PROT3>3.0.CO;2-H

Jansen, J.M., Hummel, H., Bonga, S.W., 2009. The respiratory capacity of marine mussels (Mytilus galloprovincialis) in relation to the high temperature threshold. Comp. Biochem. Physiol. A. Mol. Integr. Physiol. 153, 399-402. https://doi.org/10.1016/j.cbpa.2009.03.013

Johnson, K.S., Beehler, C.L., Sakamoto-Arnold, C.M., Childress, J.J., 1986. In Situ Measurements of Chemical Distributions in a Deep-Sea Hydrothermal Vent Field. Science 231, 1139-1141. https://doi.org/10.1126/science.231.4742.1139

Johnson, K.S., Childress, J.J., Hessler, R.R., Sakamoto-Arnold, C.M., Beehler, C.L., 1988. Chemical and biological interactions in the Rose Garden hydrothermal vent field, Galapagos spreading center. Deep Sea Res. Part Oceanogr. Res. Pap. 35, 1723-1744. https://doi.org/10.1016/0198-0149(88)90046-5

Lwebuga-Mukasa, J., 1970. The role of elytra in the movement of water over the surface of Halosydna brevisetosa (Polychaeta: Polynoidae). Bull. South Calif. Acad. Sci. 69, 154160.

Mangum, C.P., 1978. Temperature adaptation, in: Physiology of Annelids. PJ Mill, pp. 447478.

May, D.R., 1972. THE EFFECTS OF OXYGEN CONCENTRATION AND ANOXIA ON RESPIRATION OF ABARENICOLA PACIFICA AND LUMBRINERIS ZONATA (POLYCHAETA) ,. Biol. Bull. 142, 71-83. https://doi.org/10.2307/1540247

Norlinder, E., Nygren, A., Wiklund, H., Pleijel, F., 2012. Phylogeny of scale-worms (Aphroditiformia, Annelida), assessed from 18SrRNA, 28SrRNA, 16SrRNA, mitochondrial cytochrome c oxidase subunit I (COI), and morphology. Mol. Phylogenet. Evol. 65, 490-500. https://doi.org/10.1016/j.ympev.2012.07.002

Podowski, E., Ma, S., Luther, G., Wardrop, D., Fisher, C., 2010. Biotic and abiotic factors affecting distributions of megafauna in diffuse flow on andesite and basalt along the Eastern Lau Spreading Center, Tonga. Mar. Ecol. Prog. Ser. 418, 25-45. https://doi.org/10.3354/meps08797 
Podowski, E.L., Moore, T.S., Zelnio, K.A., Luther, G.W., Fisher, C.R., 2009. Distribution of diffuse flow megafauna in two sites on the Eastern Lau Spreading Center, Tonga. Deep Sea Res. Part Oceanogr. Res. Pap. 56, 2041-2056. https://doi.org/10.1016/j.dsr.2009.07.002

Pörtner, H.-O., Bock, C., Mark, F.C., 2017. Oxygen- and capacity-limited thermal tolerance: bridging ecology and physiology. J. Exp. Biol. 220, 2685-2696. https://doi.org/10.1242/jeb.134585

Projecto-Garcia, J., Le Port, A.-S., Govindji, T., Jollivet, D., Schaeffer, S.W., Hourdez, S., 2017. Evolution of single-domain globins in hydrothermal vent scale-worms. J. Mol. Evol. 85, 172-187. https://doi.org/10.1007/s00239-017-9815-7

Prosser, C.L., 1955. PHYSIOLOGICAL VARIATION IN ANIMALS. Biol. Rev. 30, 229-261. https://doi.org/10.1111/j.1469-185X.1955.tb01208.x

Ravaux, J., Hamel, G., Zbinden, M., Tasiemski, A.A., Boutet, I., Léger, N., Tanguy, A., Jollivet, D., Shillito, B., 2013. Thermal Limit for Metazoan Life in Question: In Vivo Heat Tolerance of the Pompeii Worm. PLoS ONE 8, e64074. https://doi.org/10.1371/journal.pone.0064074

Seibel, B.A., 2007. On the depth and scale of metabolic rate variation: scaling of oxygen consumption rates and enzymatic activity in the Class Cephalopoda (Mollusca). J. Exp. Biol. 210, 1-11. https://doi.org/10.1242/jeb.02588

Sunday, J.M., Bates, A.E., Dulvy, N.K., 2011. Global analysis of thermal tolerance and latitude in ectotherms. Proc. R. Soc. B Biol. Sci. 278, 1823-1830. https://doi.org/10.1098/rspb.2010.1295

Taylor, A.C., 1976. The respiratory responses of Carcinus maenas to declining oxygen tention. J Exp Biol 65, 309-322.

Tunnicliffe, V., 1992. The Nature and Origin of the Modern Hydrothermal Vent Fauna. PALAIOS 7, 338. https://doi.org/10.2307/3514820

Van Dover, C.L., Fry, B., 1994. Microorganisms as food resources at deep-sea hydrothermal vents. Limnol. Oceanogr. 39, 51-57. https://doi.org/10.4319/lo.1994.39.1.0051

Weber, R.E., 1978. Respiration, in: Physiology of Annelids. PJ Mill, pp. 369-393. 
Table 1: Specimens used in this study. Species listed in alphabetical order, expedition, habitat, depth, and range of typical temperatures encountered. A range of wet weights is provided for each species. CVR=Closed Vessel Respirometry; FTR= Flow-Through Respirometry; Temp $=$ effect of Temperature; $\mathrm{Oxy}=$ Oxyregulation .

\begin{tabular}{|c|c|c|c|c|c|c|c|c|}
\hline Species & Sampling expedition & Habitat type & Site name & Coordinates & $\begin{array}{l}\text { Depth } \\
(\mathrm{m})\end{array}$ & $\begin{array}{c}\text { Temp } \\
\text { range }\left({ }^{\circ} \mathrm{C}\right)\end{array}$ & $\begin{array}{l}\text { Specimens } \\
\text { studied }\end{array}$ & $\begin{array}{c}\text { Wet } \\
\text { weight }(\mathrm{g})\end{array}$ \\
\hline Branchinotogluma grasslei & EPR2002 & Hydrothermal vent & $9^{\circ} \mathrm{N}$ & $9^{\circ} 49.80^{\prime} \mathrm{N} 104^{\circ} 17.40^{\prime} \mathrm{W}$ & 2700 & $10-25$ & $2 \mathrm{CVR}$ & $0.347^{*}$ \\
\hline Branchinotogluma hessleri & EPR2002 & Hydrothermal vent & $9^{\circ} \mathrm{N}$ & $9^{\circ} 49.80^{\prime} \mathrm{N} 104^{\circ} 17.40^{\prime} \mathrm{W}$ & 2700 & $10-25$ & $1 \mathrm{CVR}$ & 0.037 \\
\hline Branchinotogluma sp. nov. & CHUBACARC & Hydrothermal vent & Mangatolo & $15^{\circ} 57.24^{\prime} \mathrm{S} 174^{\circ} 42.66^{\prime} \mathrm{W}$ & 1330 & $3-5$ & $1 \mathrm{FTR}$ & 0.385 \\
\hline Branchinotogluma segonzaci & CHUBACARC & Hydrothermal vent & Solwara 8 & $3^{\circ} 43.50^{\prime} \mathrm{S} 151^{\circ} 40.20^{\prime} \mathrm{E}$ & 1500 & $20-30$ & $\begin{array}{l}2 \text { FTR, } \\
2 \text { Temp, } \\
1 \text { Oxy }\end{array}$ & $\begin{array}{r}0.310- \\
2.761\end{array}$ \\
\hline Branchinotogluma trifurcus & CHUBACARC & Hydrothermal vent & $\begin{array}{l}\text { Tu'i Malila } \\
\text { Tow Cam }\end{array}$ & $\begin{array}{l}21^{\circ} 59.26^{\prime} \mathrm{S} 176^{\circ} 34.07^{\prime} \mathrm{W} \\
20^{\circ} 19.01^{\prime} \mathrm{S} 176^{\circ} 08.20^{\prime} \mathrm{W}\end{array}$ & $\begin{array}{l}1850 \\
2700\end{array}$ & $10-20$ & $\begin{array}{l}4 \text { FTR, } \\
1 \text { Temp }\end{array}$ & $\begin{array}{r}0.132- \\
0.205\end{array}$ \\
\hline Branchipolynoe tjiasmantoi & CHUBACARC & Hydrothermal vent & $\begin{array}{l}\text { Kulo Lasi } \\
\text { Tu'i Malila } \\
\text { ABE }\end{array}$ & $\begin{array}{l}14^{\circ} 55.20^{\prime} \mathrm{S} 177^{\circ} 15.00^{\prime} \mathrm{W} \\
21^{\circ} 59.26^{\prime} \mathrm{S} 176^{\circ} 34.07^{\prime} \mathrm{W} \\
20^{\circ} 45.71^{\prime} \mathrm{S} 176^{\circ} 11.46^{\prime} \mathrm{W}\end{array}$ & $\begin{array}{l}1480 \\
1850 \\
2200\end{array}$ & $6-8$ & $\begin{array}{l}3 \text { FTR, } \\
2 \text { Temp }\end{array}$ & $\begin{array}{r}0.463- \\
1.786\end{array}$ \\
\hline Branchipolynoe aff. seepensis & WACS & Cold seeps & REGAB & $5^{\circ} 46.89^{\prime} \mathrm{S} 9^{\circ} 44.66^{\prime} \mathrm{E}$ & 3200 & 4 & $\begin{array}{r}3 \mathrm{FTR} \\
3 \mathrm{Oxy}^{* *} \\
\end{array}$ & $\begin{array}{r}1.288- \\
1.552 \\
\end{array}$ \\
\hline Branchipolynoe symmytilida & MESCAL, EPR2002 & Hydrothermal vent & $9^{\circ} \mathrm{N}$ & $9^{\circ} 49.80^{\prime} \mathrm{N} 104^{\circ} 17.40^{\prime} \mathrm{W}$ & 2700 & $6-8$ & $\begin{array}{r}42 \text { CVR, } \\
1 \text { FTR, } \\
1 \text { Oxy } \\
\end{array}$ & $\begin{array}{r}0.008- \\
4.650\end{array}$ \\
\hline Eulagiscinae gen. sp. & CHUBACARC & Deep sea, non-vent & Fatu Kapa & $3^{\circ} 43.50^{\prime} \mathrm{S} 151^{\circ} 40.20^{\prime} \mathrm{E}$ & 1500 & 4 & $1 \mathrm{FTR}$ & 0.346 \\
\hline Gattyana cirrhosa & Roscoff Marine lab & Coastal temperate & Penpoul & $48^{\circ} 40.77^{\prime} \mathrm{N} 3^{\circ} 56.89^{\prime} \mathrm{W}$ & $0-10$ & $12-20$ & $1 \mathrm{FTR}$ & 0.807 \\
\hline Harmothoe extenuata & Roscoff Marine lab & Coastal temperate & Ile Verte & $48^{\circ} 43.76^{\prime} \mathrm{N} 3^{\circ} 59.24^{\prime} \mathrm{W}$ & $0-10$ & $12-20$ & $\begin{array}{l}2 \text { FTR } \\
1 \text { Oxy } \\
\end{array}$ & $\begin{array}{r}0.134- \\
0.361\end{array}$ \\
\hline Lepidonotopodium fimbriatum & MESCAL & Hydrothermal vent & $9^{\circ} \mathrm{N}$ & $9^{\circ} 49.80^{\prime} \mathrm{N} 104^{\circ} 17.40^{\prime} \mathrm{W}$ & 2700 & $25-30$ & $\begin{array}{r}2 \text { FTR, } \\
1 \text { Oxy }\end{array}$ & $\begin{array}{r}0.553- \\
0.624 \\
\end{array}$ \\
\hline Lepidonotopodium williamsae & $\begin{array}{l}\text { MESCAL, } \\
\text { MESCAL2, EPR2002 }\end{array}$ & Hydrothermal vent & $9^{\circ} \mathrm{N}$ & $9^{\circ} 49.80^{\prime} \mathrm{N} 104^{\circ} 17.40^{\prime} \mathrm{W}$ & 2700 & $12-15$ & $4 \mathrm{CVR}$ & $\begin{array}{r}0.311- \\
1.163 \\
\end{array}$ \\
\hline Levensteiniella raisae & CHUBACARC & Hydrothermal vent & $\begin{array}{l}\text { Solwara } 8 \\
\text { Tu'i Malila }\end{array}$ & $\begin{array}{l}3^{\circ} 43.5^{\prime} \mathrm{S} 151^{\circ} 40.2^{\prime} \mathrm{E} \\
21^{\circ} 59.26^{\prime} \mathrm{S} 176^{\circ} 34.07^{\prime} \mathrm{W}\end{array}$ & $\begin{array}{l}1520 \\
1800\end{array}$ & $7-10$ & 7 FTR & $\begin{array}{r}0.102- \\
5.126 \\
\end{array}$ \\
\hline
\end{tabular}




\begin{tabular}{|c|c|c|c|c|c|c|c|c|}
\hline Pettibonesia furcosetosa & Roscoff Marine lab & Coastal temperate & Penpoul & $48^{\circ} 40.77^{\prime} \mathrm{N} 3^{\circ} 56.89^{\prime} \mathrm{W}$ & $0-10$ & $12-20$ & $\begin{array}{r}11 \text { FTR, } \\
1 \text { Oxy }\end{array}$ & $\begin{array}{r}0.134- \\
0.658\end{array}$ \\
\hline Thermiphione sp. & CHUBACARC & Deep sea & Tu'i Malila & $21^{\circ} 59.26^{\prime} \mathrm{S} 176^{\circ} 34.07^{\prime} \mathrm{W}$ & 1850 & 4 & $\begin{array}{l}3 \text { FTR, } \\
1 \text { Temp }\end{array}$ & $\begin{array}{r}0.126- \\
1.186 \\
\end{array}$ \\
\hline Thermopolynoe branchiata & CHUBACARC & Hydrothermal vent & $\begin{array}{l}\text { North } \mathrm{Su} \\
\text { Solwara } 8 \\
\text { ABE } \\
\text { Tow Cam }\end{array}$ & $\begin{array}{l}3^{\circ} 48.00^{\prime} \mathrm{S} 152^{\circ} 6.00^{\prime} \mathrm{E} \\
3^{\circ} 43.50^{\prime} \mathrm{S} 151^{\circ} 40.20^{\prime} \mathrm{E} \\
20^{\circ} 45.71^{\prime} \mathrm{S} 176^{\circ} 11.46^{\prime} \mathrm{W} \\
20^{\circ} 19.01^{\prime} \mathrm{S} 176^{\circ} 08.20^{\prime} \mathrm{W}\end{array}$ & $\begin{array}{l}1200 \\
1500 \\
2200 \\
2700 \\
\end{array}$ & $8-14$ & $\begin{array}{l}8 \text { FTR, } \\
2 \text { Temp, } \\
1 \text { Oxy }\end{array}$ & $\begin{array}{r}0.074- \\
2.946\end{array}$ \\
\hline
\end{tabular}

* two measurements on the same specimen. ${ }^{* *}$ All experiments at $4^{\circ} \mathrm{C}$ for this species. 
Table 2: Arrhenius plot slopes for experimental animals whose oxygen consumption was measured while ramping the temperature at $1^{\circ} \mathrm{C} / 10$ minutes. Each line corresponds to a distinct experimental animal. See figure 3 and supplementary figure 1 for the Arrhenius plots.

\begin{tabular}{llc}
\hline Species & Habitat & Slope \\
\hline Gattyana cirrhosa & Shallow-water temperate & -1.17 \\
Thermiphione sp. & Deep sea & -1.42 \\
Branchinotogluma segonzaci & Hydrothermal vent chimneys & -1.56 \\
& & -3.49 \\
Branchinotogluma trifurcus & Hydrothermal vents among Ifremeria snails & -2.36 \\
Branchipolynoe tjiasmantoi & Hydrothermal vents commensal of mussels & -2.24 \\
& & -2.50 \\
Thermopolynoe branchiata & Hydrothermal vents among Ifremeria snails & -2.54 \\
& & -1.93 \\
\hline
\end{tabular}


Figure legends

Figure 1: Specific oxygen consumption rates as a function of environmental oxygen concentration for A two shallow-water temperate species (, Pettibonesia furcosetosa, and Harmothoe extenuata), and B cold-seep species (Branchipolynoe aff. seepensis), and deep-sea hydrothermal vent species (Branchinotogluma segonzaci, Branchipolynoe symmytilida, Thermopolynoe branchiata, Lepidonotopodium fimbriatum). Measurements performed at $10^{\circ} \mathrm{C}$ for all species except the cold-seep species $\left(4^{\circ} \mathrm{C}\right)$ in the flow-through system. Oxygen concentration was modified in the inlet water by bubbling either pure nitrogen or air. Experiments lasted up to 36 hours.

Figure 2: A. $\log / \log$ representation of the specific oxygen consumption rates as a function of wet weight for specimens from different habitats or lifestyles. Regression line fitted to all datapoints: $y=-0.353 x+0.2258, r^{2}=0.2481, p<0.001$. B. Distribution of $\log$ (specific oxygen consumption rates) residuals to the regression in A. Hydrothermal non-symbiotic $(n=28)$, deepsea $(n=4)$, Hydrothermal symbiotic $(n=43)$, and coastal shallow-water $(n=9)$. All measurements at $10^{\circ} \mathrm{C}$.

Figure 3: Arrhenius plots for $\log$ (oxygen consumption rates) measured on single individuals. For the X-axis, the inverse of temperature (in Kelvin) was multiplied by 1000 and the axis was reversed to keep low temperature values to the left for ease of reading. Corresponding axis with temperatures in ${ }^{\circ} \mathrm{C}$ is provided on top of each graph. A. Gattyana cirrhosa (shallow-water temperate), B. Branchipolynoe tjiasmantoi (hydrothermal vent mussel commensal), and C. Thermopolynoe branchiata (hydrothermal vent, free-living). See supplementary figure 1 for the remaining plots. 
Figure 1
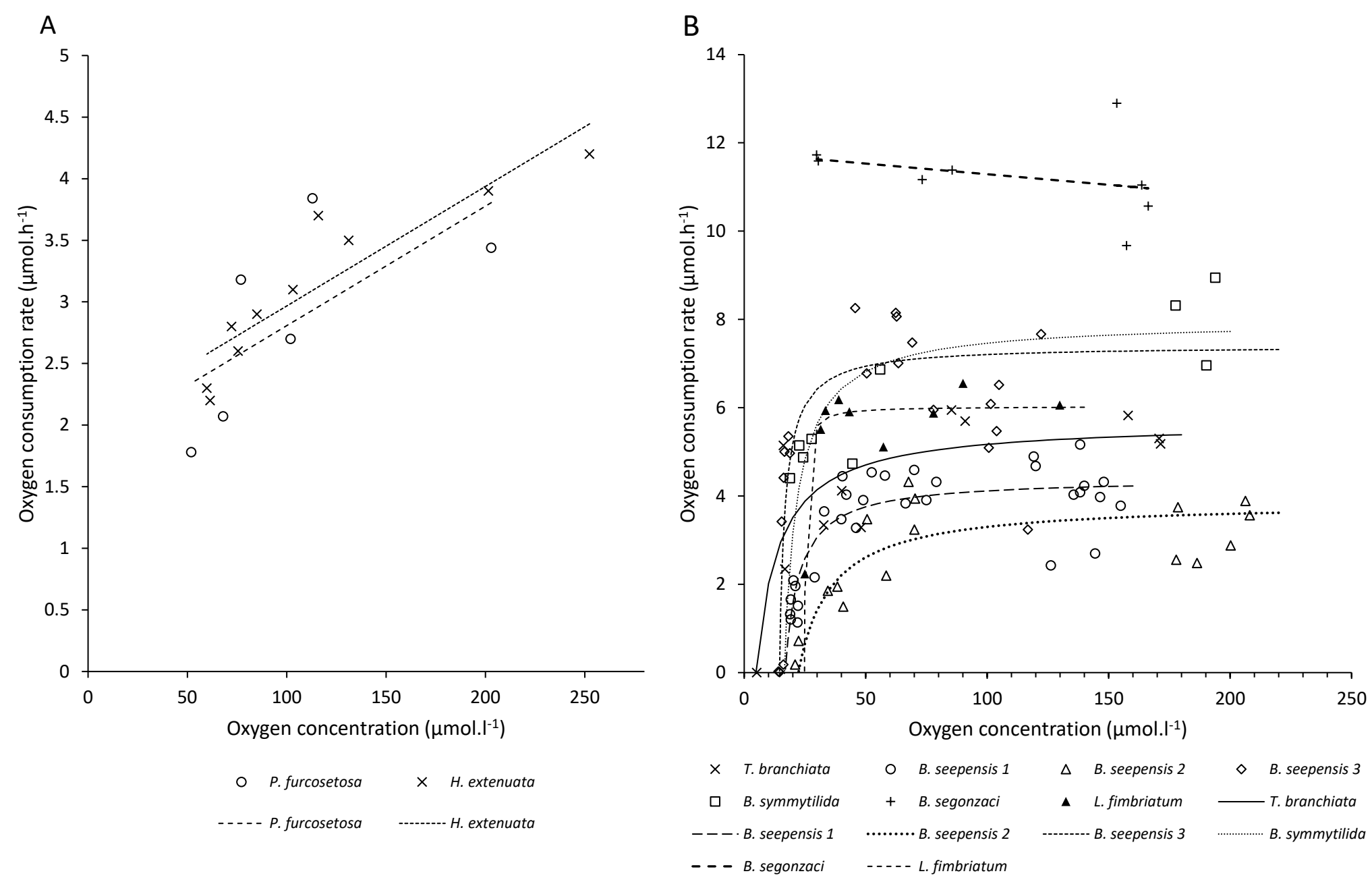
Figure 2

A

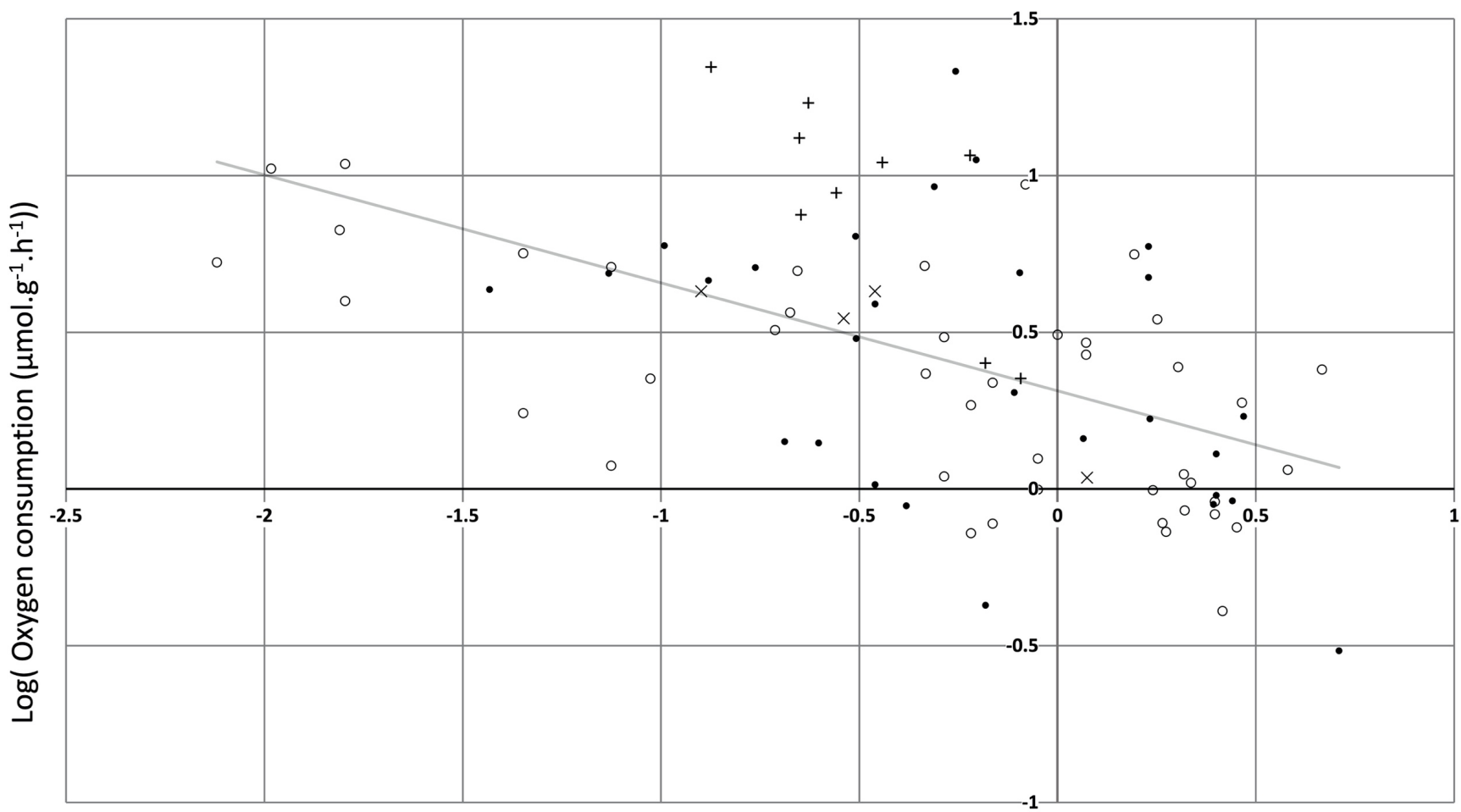

Log( Wet Weight (g))

- Hydrothermal non-symbiotic $\times$ Deep-sea + Coastal shallow-water $\circ$ Hydrothermal symbiotic

B

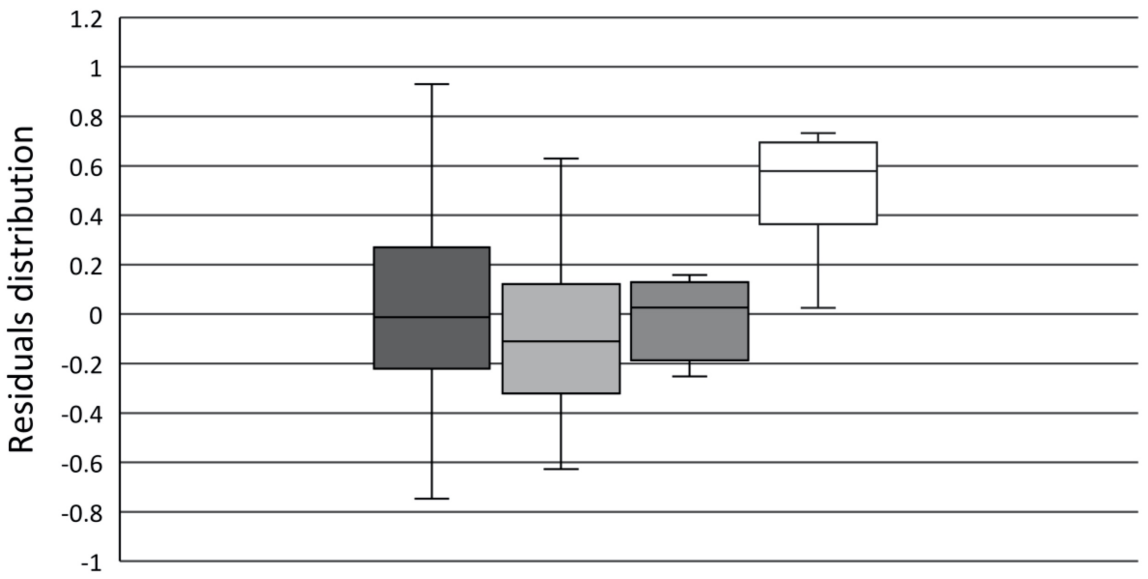

$\square$ Hydrothermal non-symbiotic $\square$ Hydrothermal symbiotic

$\square$ Deep-sea

$\square$ Coastal shallow-water 
Figure 3
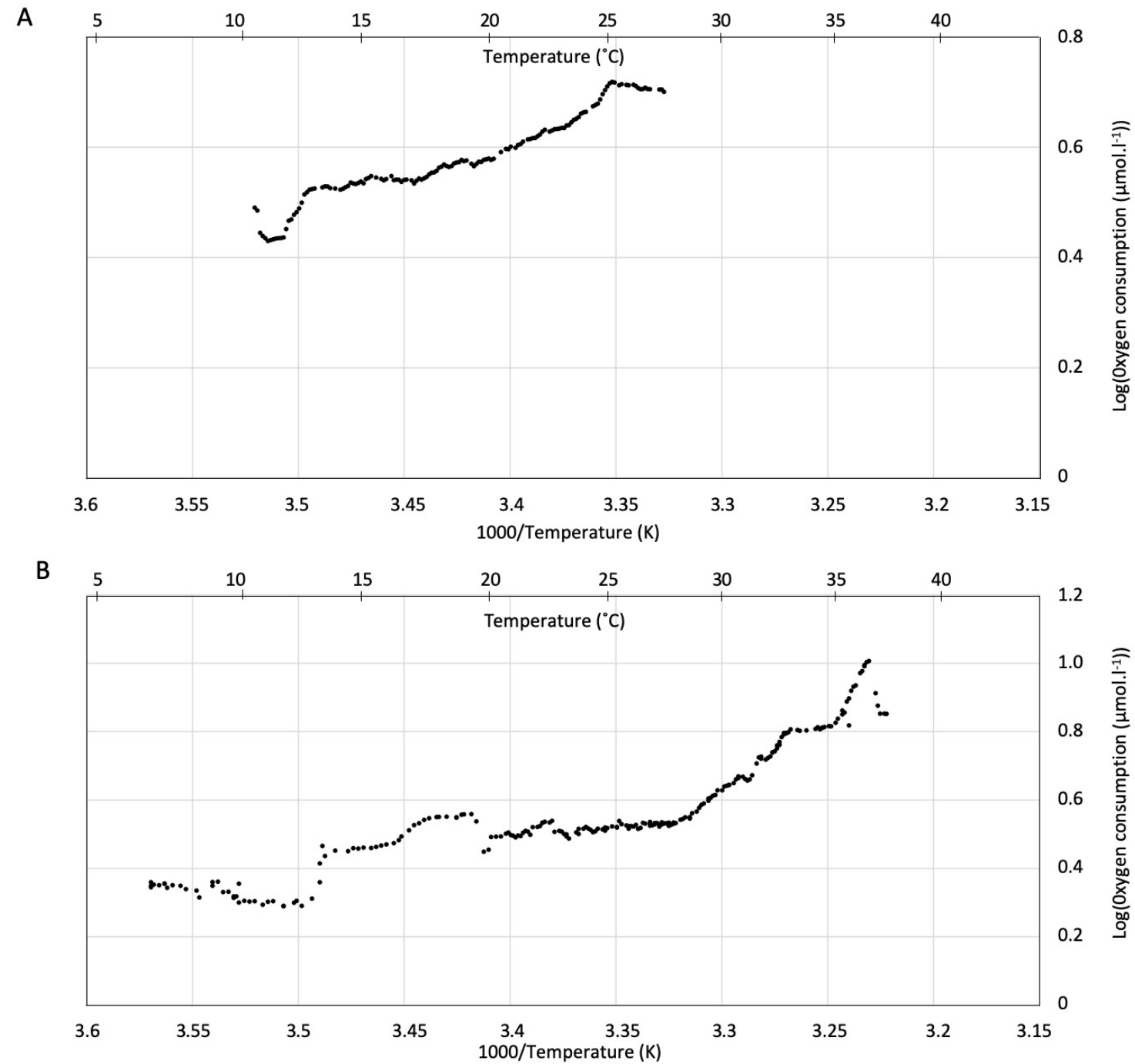

C

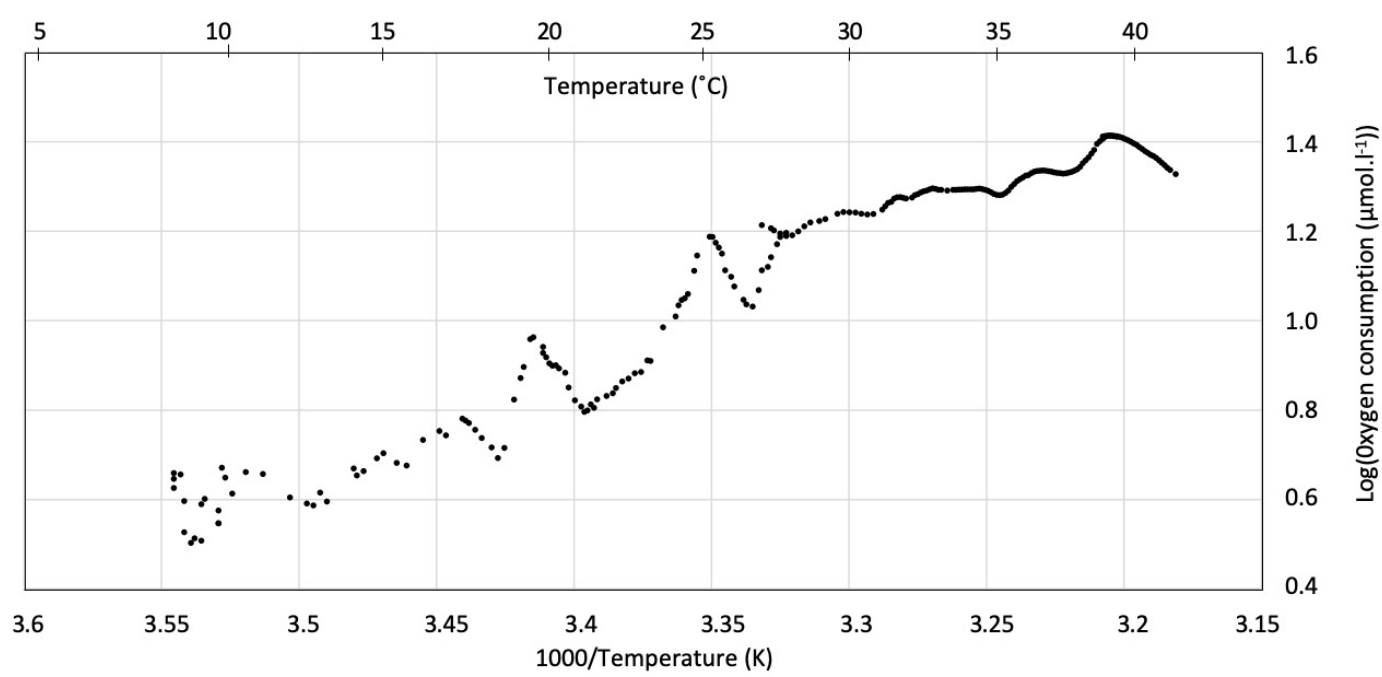


Supplementary figure legend

\section{Supplementary figure 1:}

Arrhenius plots for $\log$ (oxygen consumption rates). For the $\mathrm{X}$-axis, the inverse of temperature (in Kelvin) was multiplied by 1000 and the axis was reversed to keep low temperature values to the left for ease of reading. A. Thermopolynoe branchiata, B and C. Branchinotogluma segonzaci, D. Branchinotogluma trifurcus, E. Branchipolynoe tjiasmantoi, and F. Thermiphione sp.. A-E Deep-sea hydrothermal vent species. F. Deep-sea species. 
Supplementary figure 1
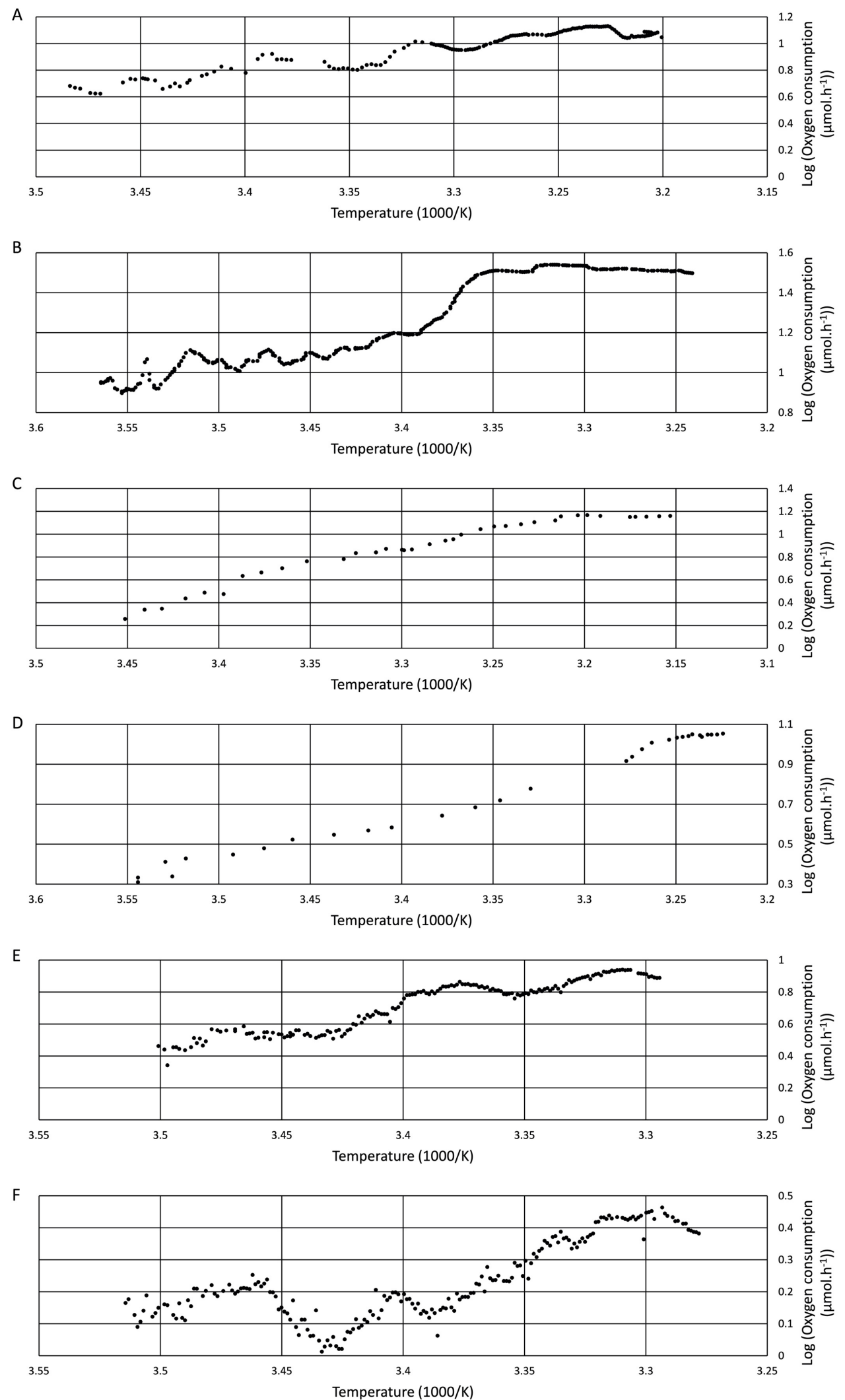